\title{
War Pics: Photographic Representations of the Colonial War
}

\author{
Paulo de Medeiros
}

\begin{abstract}
A análise das representaçð̃es da guerra colonial tem sido escassa e limitada a textos literários. Este artigo pretende examinar as fotografias da guerra colonial que foram publicadas em livros tendo em conta a sua relativa escassez e o facto de não haver dados sobre as condiçð̃es de produção dessas imagens. Tenta-se assim uma reflexão preliminar sobre a fotografia de guerra no contexto específico da guerra colonial. A guerra colonial aparece através destas imagens como uma actividade quase pré-moderna, e até a morte parece tornar-se banal. Algumas das imagens mais marcantes são analisadas em pormenor sendo de salientar que embora não haja romanticização da guerra, há sim processos de romantização e de ironização dos soldados portugueses assim como uma espécie de fetichização dos cadáveres de africanos.
\end{abstract}

É assim que me lembro, ainda que para nada - disse de novo Eva Lopo - das caixas e dos envelopes selados que saíram do cofre.... Por dentro das caixas havia envelopes, e dentro dos envelopes, amarradas com elásticos, as fotografias arrumavam-se por operações.

Lídia Jorge 131

The twentieth-century might as well be characterized by extreme and horrific wars as well as by a predominance of the visual over all other forms of cultural production and communication. First photography, and then cinema and television have not only disrupted traditional aesthetic assumptions and categories but also imposed themselves over all other art forms and print media. Theoretical reflection on cinema developed on par with other reflections on literature and painting; and television, at least on line with studies over mass culture and marketing, has also been the object of intense and widespread studies. Photography, however, remained for a long time outside of the scope of the humanities except for historical studies. It is only in the last ten years or so that studies of photography deploying theoretical approaches have been gaining ground and seminal studies such as that of Susan Sontag and Roland Barthes are still not only widely cited but the object of commentary in themselves. One area of reflection on photography that is still underdeveloped is war photography. And yet, perhaps no other relation has had more impact. As Leslie Deveraux comments in her introduction to a recent collection of essays on film, photography and visual anthropology, "The way the photograph, once it exists, comes to have and to exercise beyond full intentional control its own force was revealed in the television and newspaper politics of the Vietnam War and may well have led quite directly to Pentagon decisions to restrict access to journalists and photographers to the Gulf ground war in 1991" (1).

Photographs are not only powerful objects, they exert power; and since wars are always power conflicts one could have expected that precisely the examination of war photographs might have served as a basis for theoretical reflections of the medium. Instead, the current 
bibliography is sparse, limited to a few books and articles and almost invariably centered on one of the two great wars and limited to the central powers involved. Moreover, if one keeps in mind the lesson of both Sontag and Barthes, photographs are always about death. They might give us the illusion of denying time and subverting death by concentrating on a moment and preserving the appearance of life but, in actuality, they arrest the moment and thus already always can only represent that which is no more. Of all human activities perhaps no other is more directly linked with death than war and so another reason could be invoked to examine war photography. That and the fact that just like almost all memorials are memorials to war dead, so photography from its beginning has been intrinsically linked, more than any other medium, with processes of memory and personal remembrance. Although a rigorous assessment for the discrepancy between the direct linkage between war and photography and its study might be difficult, one might look at photography's documentary and aesthetic qualities as possible causes. As Bernd Hüppauf asks, "Is the aesthetic thrill associated with images of ruins, a field of destruction, of violence and death amoral, or would it have to be seen as part of an aesthetic sphere divorced from that of moral value judgment?" (97). But when viewing war photographs it might be impossible to separate ethics from aesthetics.

The question of what defines a good war photograph might appear absurd, if not perverse, but it quickly points out at the dilemma that might lie at the base of the scarcity of interest in war photographs. The relation between war and photography hinges on a paradoxical association between the photograph's claim to veracity and its status as representation. These are questions that have been at the core of all discussion on photography and not just of war photography, but in the concrete case of war photography they become exarcebated. Photography's claim for truth, for representing reality as it really is with as least subjective control as possible, is one which soon was questioned and might be disappearing with the introduction of digital processes. But it still lives on in popular sentiment. Thus, on the one hand, war photographs for many are not only the one way in which they can imagine what circumstances at the front might be like, they can be said to depict exactly what those circumstances are or were. On the other hand, any photograph, including those seemingly taken by chance, cannot escape the fact that either at the moment of production, but certainly at the moment of reception, they will be filtered through codes of representation that are primarily aesthetic and pre-determined. A great number of war photographers have as explicit aim a critique of war's destruction and inhumanity or an affirmation of human or national assumed characteristics of nobility, courage, heroism and sacrifice, and so many war photographs, even as they remain tied to codes of realism will always already be ideologically charged from the beginning. To say nothing of course of famous photographs which much later were found, or at least suspected of, having been carefully manipulated to achieve a desired effect. Perhaps the two most famous examples are the well-known photograph by Fred Roesenthal of soldiers raising the American flag atop a hill in Iwo Jima and Robert Capa's image of the Spanish Civil War, "Moment of Death for a Loyalist Soldier" in which a partisan is seen at the moment he is hit by a bullet.

Regardless of whatever manipulation a given photograph might undergo, the answer as to the quality of a war photograph seems to reside in its effect to raise the audience's feelings. Susan D. Moeller in her study of American war photography is very explicit on this point: "Usually the images that are recalled are those that live in infamy; they are memorable and persuasive because they are the most compelling, the most horrifying. Three such pictures from the Vietnam War, for instance, are the photographs of the burning Buddhist monk, the executed North Vietnamese, and the napalmed child" (19). Such images attain an iconicity that transports them beyond their immediate and particularized historical context and allows them to stand in for a whole range of ideological premises. Even if to remain 
effective those images must be over and over again reinserted into their contextual frame, and their initial ability to shock audiences significantly decreases with the passing of time, they acquire new meanings as symbols of inhumanity, of resistance to oppression and so on. But the majority of war photographs is never lifted out in such a way and even when published, they often are "aesthetically and conceptually boring" (Moeller, 18) and it is more likely that they will soon be displaced by the continuous production of images of catastrophes and horrors, so as to become what Moeller terms "muddy squares in the pages of newspapers and magazines" (18). And yet, were one to seize only on the most shocking pictures of war one would necessarily falsify any attempt at understanding not only the peculiar aesthetics of war photography but, more importantly, their relation to ethical issues.

My aim in the present essay is to attempt a first consideration of the photographs of the Portuguese colonial war. I am interested in them primarily as images and not as symbols for ideological programs, but without ever forgetting the impossibility to separate the ethical issues from the aesthetic ones since that is what, in my opinion, is so marking of war photographs. Lasting thirteen years, from 1961 to 1975, the war against the different movements of national liberation in the former Portuguese colonies in Africa had devastating consequences for all of Portuguese society and marked as well not only the last throes of Portugal's imperial dreams but also the end of European colonialism. This would seem reason enough for detailed considerations of such a war not simply in historical terms but also as far as its representations are concerned. Yet the opposite is true. Perhaps the equally far-reaching consequences, in European terms, of the April Revolution in Portugal, which restored democratic rule to the nation after five decades of oppression, have something to do with it as I have had occasion to argue in another essay.

Be that as it may be, public discussion of the colonial war has never taken place in Portugal. Like one of the characters in João Botelho's film, Um Adeus Português, who stopped telling people that his brother was killed in the colonial war, pretending instead that he was a victim of a car accident, to avoid making them feel uneasy, Portuguese society seems to have simply put aside admitting, let alone discussing, the fact of the colonial war. Whatever reflection has taken place on the war it has been primarily effected through fictional narrative. And, in spite of the fact that a number of celebrated contemporary authors have authored significant novels thematizing the war only very recently have these begun to be studied. Given the scarcity of studies of war photographs in general and the resistance to reflect on the representation of the Portuguese colonial war in particular, photographs of this war appear to have simply been forgotten.

The passage cited as epigraph introduces a key scene in Lídia Jorge's $A$ Costa dos Murmúrios, widely recognized as one of the most important novels to adress the Portuguese colonial wars in Africa. In that scene the narrator, Eva, recalls how as a young woman she discovered what her recently-wed husband had become, a sadist killer, at the same time that she discovers the atrocious nature of the colonial war. It is through the photographs coming out of the sealed envelopes in the coffer that Evita - as she called herself then - first assumes a different consciousness about herself and the reality surrounding her. The centrality of photography for an understanding of the war is one of the points Lídia Jorge makes and one that has been ignored. Like the photographs in that novel, which function as a poisoned secret, kept in a coffer and sealed in envelopes labeled "spoilt", the actual photographs of the colonial remain to a certain extent hidden away.

Full consideration of those photographs is impossible for a variety of reasons, starting with the fact that given the strict censorship of the Press in Portugal, images of the war were infrequent, down to the fact that the military archives still have not released such materials. The photographs that can be easily consulted today were published in three books and originate for the most part with individuals who possess the originals, which already 
signifies a severe limitation as to the type of photographs that can be discussed. One book, 4 Paises Libertados, was published almost after the revolution, in 1975. It mentions that many of its images come from the Army archives and also that these archives burnt down on 22 June, 1975. Other institutions also mentioned as providing photos are the Arquivo Fotográfico of the Direcção Geral de Informação, the Ministério de Comunicação Social and the Centro de Informações e Documentação Anticolonial, as well as the photo archive of Diário Popular. Many of those images are reproduced in the two other books, although a number of photographs depicting activities of the liberation movements are not. The first of those two other books, Os Anos da Guerra, was edited by João de Melo, one of the writers to publish novels on the war and who also started critical reflection on the representations of the war. Its first edition in two volumes was published in 1988 and contained a large number of narratives by over fifty different authors both Portuguese as well as African. The photographs it contains, in a total of 261 , are included as a form of complement to the texts. The second book, edited by Renato Monteiro and Luís Farinha two years later, is significantly titled Guerra Colonial, Fotobiografia and its emphasis is on the pictorial so that the text it contains is for the most part explanatory. Besides a large number of images that are not properly photographs, such as posters, and other documents, this book includes 317 photographs. All in all then, there are just over five hundred photographs of the colonial war readily available which, even given the limitations already mentioned, can reasonably serve as a significant base from which to try to formulate some critical notions on the photographic representations of the colonial war.

The first impression one has of the colonial war from its photographs is that it was a pre-modern war. Of course a colonial war, unlike a conventional one, is not prone to great displays of war machinery or large combat fields, being much more a compilation of small encounters, hide and seek deadly games, punitive expeditions, ambushes and so on. But still, when one goes through the five hundred or so published photographs of the war one is left with the feeling that this was a primitive war fought under the most primitive conditions. By looking at some of the photographs and seeing the Portuguese soldiers with their heavy metal helmets on one could think they were going to the trenches in World War I and not to the tropical climates of Africa in the sixties. But above all what gives the feeling of a premodern conflict is, on the one hand, the almost complete absence of aerial photographs, and on the other hand, the almost complete lack of any form of war material. War is to a great extent a question of technology and whatever technology is deployed in these photographs it appears hopelessly out of date or wrecked.

The first issue then is the lack of aerial photographs that have been determinant for any war beginning with World War I. This might be explained by the fact that the great majority of these images were taken by soldiers themselves and others around them and are thus private, and not official, photographs of the conflict. It is unclear who would have taken the photographs depicting elements of the different liberation movements in activity, either training, or resting, or marching. The majority, though not all, of these appear in 4 Paises Libertados, and one can say that on the whole they tend to portray the liberation warriors as human, civilized, and disciplined, quite in contrast to the views propagated by Portuguese propaganda of them as "terrorists". It may well be that the military archives contain - or contained, before the fire - boxes and boxes of aerial surveillance photographs, showing the topography of the colonies as scarred landscapes devoid of human figurants, or testifying to the devastation caused by bombings of villages and forest tracts. Maybe those archives also contained imposing photographs of modern planes and bombs. Maybe even some of the soldiers also took some of those photographs and they were just not selected for publication. The problem of the framing of these photographs within three books which have not only a documentary purpose but also a clear interest in condemning the war account for the absence 
of such photographs. But that is not important. What matters is that as a result a certain image of the war is achieved through the published photographs and that is of a personal, sometimes almost individual, conflict in a desolate and for the most part barren landscape.

The most advanced bellic material is shown in a small photograph of a few Fiat G-91 jet fighters on the ground with a smiling pilot in one of the open cockpits and one has the sense that this is as removed from the atrocities of war as possible. Never mind that at the time even that airplane was already obsolete by western standards, it is the closest one gets to have a sense that this war took place in the sixties and seventies. Other aircraft are shown, but all of them, with the possible exception of the light French Alouette helicopters, were hopelessly antiquated. There is a photograph of a transport plane used to take paratroopers into action and another of what, described as a light bomber plane, was in reality a converted instruction plane, the T-33. It is not only that the helicopters were more appropriate machines for that type of conflict, it is also that they are represented as in action, either dropping soldiers into the ground or receiving wounded to be transported back to the base. Those are photographs that depend on the moment and are highly kinetic, whereas the other photographs of planes are all static and it is only by connotation, by the fact that they are included in the book, that one associates them with the war at all. One other form of heavy war equipment shown is trucks, either the ever-present Unimogs or heavier trucks for the transport of troops. Sometimes these are shown as part of convoys on patrol in the fields, other times they too are static, showing a pause during which the soldiers talk or eat. And then there are the pictures of the wrecks, vehicles stuck in mud or blown away by mines. Besides these there are also pictures of wrecked airplanes and even of a capsized helicopter. If one takes the combined photographs of heavy equipment together the impression left is one of inadequacy, of antiquity, of lack, and of failure.

The face of modern warfare is largely mechanical and this has been pointed out as yet another intrinsic contradiction of war photography, which, as much as it depends on technology itself, is bent on showing the inhuman aspects of technology and the horrific effects of the deployment of such machinery and technology. As Hüppauf notes, "War films with a moral commitment face the problem that the nature of their images and indeed their very structure of representation contradict the subject of their representation - that is, the destruction of humanity by modern technological-scientific warfare" (96). If one thinks about some of the photographs most laden with emotional charge in the context of the Portuguese colonial war, the departure of the soldiers to Africa, one can see this contradiction neatly exposed. Take for instance the photograph of soldiers preparing to enter a ship, forming a double helix on the docks. There is no question here of individuality but rather an attempt at showing a mass of humanity, highly organized and with a purpose. The ship itself is almost invisible in this photograph and that is perhaps as it should be since the photograph, given its slightly elevated point of view manages to present a representation of the soldiers as if they themselves constituted a machine or at least a part of a huge machine thus actually conflating the human into the technological in an image that is firmly embedded in modernist aesthetics. 


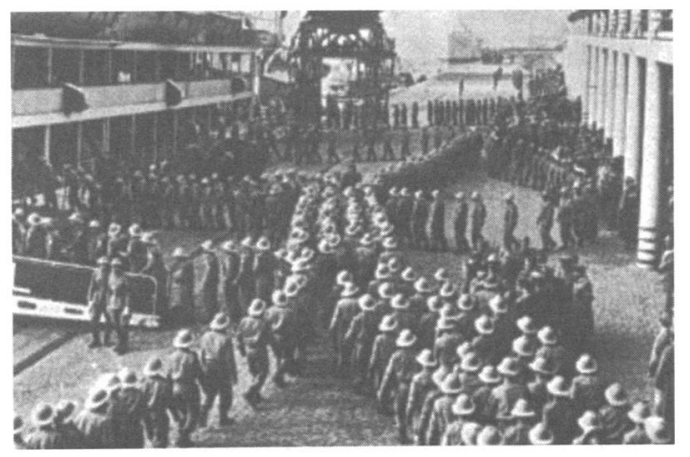

To that one can contrast the image of a ship leaving the dock with a literal human pyramid on canvas, the mass of soldiers waving good-bye to their families. This is certainly a poignant image but what is also remarkable is again how the human element, here massified and rendered indistinct has taken over the form of the machine. One can recognize that there is a ship on which the soldiers stand but the ship has become almost invisible. In both pictures there is a dwarfing of the image of machinery by the human element and, even if this human element appears itself, as a consequence, molded into the shape of a machine, nonetheless the representation of the war machine here is one that is largely suppressed. Seemingly, but only seemingly, this provides an escape out of that basic contradiction common to war photographs as noted by Hüppauf. Because, as has happened with other photographic representations of war the result is a shift into a romantic or romanticized image of human protagonists and this is a point I shall return to. But the overall effect, instead of "humanizing" the colonial war, whatever that might mean, tends to create an effect of temporal and even semantic disjunction. Not only does the colonial war look like a premodern conflict, sometimes the photographs even tend to represent it as a kind of agricultural endeavor in some remote and infertile plantation. The soldiers leaving on their trucks might be going on a deadly patrol but the photograph might as well be of day laborers going to the fields.

One isolated image, however, dispels any such notions of a pastoral enterprise lost in time. It is a highly iconic image which might well, like those infamous photographs from Vietnam mentioned by Moeller, stand alone to represent the whole war in the minds of outsiders. Taken from a helicopter it shows some village huts below and a machine gun sticking out of the lateral door of the helicopter. Aesthetically, this is an accomplished image, which immediately recalls similar images from celebrated films over the Vietnam War such as Apocalypse Now, and perhaps its inclusion in the collection might have to due precisely with such a reception framework. Unlike surveillance photos, this one still maintains a human scale and human bodies, however diminutive, are visible. But the clear menace to the lives of the African population is carried fully by the machine gun and by the opening of the helicopter which literally and figuratively frames the photograph, intimating at air superiority — the one dominant factor in every war after World War I — and creating a disproportionate size relation between the war machine and the human bodies. There are no human faces and the Portuguese soldiers are here invisible, out of the scope of the lens which, like the machine gun, is pointed at the Africans, effectively showing the implicit perspective and the paradoxical complicity between the lens and the gun. Compared to all the other photographs that still represent the colonial war as a pre-modern and even pastoral activity, this one photograph might not seem really representative. And yet, by itself, it 
suffices to annul all other photographs in their figuration of the war, as it reveals the technological basis of surveillance, control, oppression and destruction.

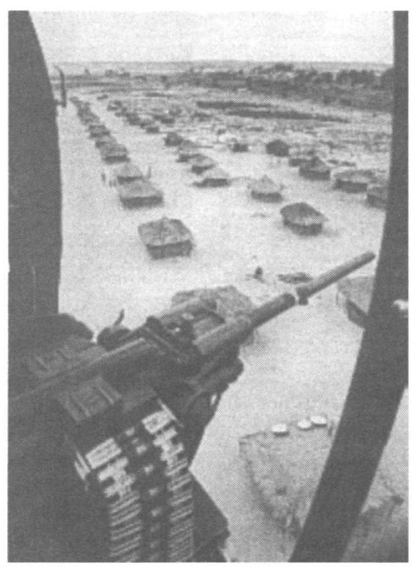

The first photographs to come out of the sealed envelopes in Lídia Jorge's novel were uninteresting: "Vejo - as primeiras dez são fotografias de colunas normais. ... Há fotografias prosaicas com soldados comendo deitados, outros enterrando latas" (131-132). Most of the photographs of the colonial war can be said to be banal. Images of soldiers resting, talking, on trucks, walking in long lines through the high grass, sitting on the ground. Even the photographs of soldiers in ambush, sometimes only their faces and the tip of their gun visible, become banal after a while as they all represent moments in which, even though all of life under war was subjacent to violence, and danger might always lurk, nothing out of the ordinary happened. Of course it might be that the convoy we see frozen on its way across a mud road would have been the target of a sudden assault the next moment after the photograph was taken or that the soldier we see eating and talking with his comrades did not have much longer to live. The photographs cannot show that and even if there would be explanatory legends, that information would remain extraneous to the image which in and by itself is banal. And yet, the fact that the viewer knows the context of the image already adds extra meaning to even the most seemingly peaceful photograph as if any photograph associated with the war would be contaminated with death.

Some of these banal images acquire an extra signification all of their own because they represent isolated moments which only make sense in the context of war and which provoke an emotional response on the part of the viewer. Take for instance the photographs of soldiers reading letters from home. They are curious photographs, as they tend to always show individual soldiers by themselves as if in isolation, reading a piece of paper. The effect, if not the intention, of such a photograph is to represent a sense of privacy, a scarce commodity in the life of any soldier, especially in conditions of war. And to represent at the same time the emotional link with home, with dear ones, with a life of assumed normalcy and relative comfort in metropolitan Portugal. A sustained analysis of such letters, if it were possible to collect them from archives or personal collections, might prove to be one of the most important studies of the representations of the colonial war. But as images these photographs of solitary soldiers reading letters from home or writing them are extremely banal. What makes them stand out is simply the context, the situation under which those pieces of paper and few lines of text acquired such great importance and which a viewer of 
the photograph can only guess at. Furthermore, the photograph is contradictory in itself and that makes its banality already acquire some interest. Because the photograph seems to depict a rare moment of privacy and a moment in which an emotional link with home and normalcy would be created that would be an attempt to deny the reality of the war. But by allowing us to see that moment the photograph has actually impinged upon that privacy, has annulled it. The viewer cannot read the letter - the photograph does not go that far - but can see the soldier reading it or writing it and so what was meant to be a private moment amidst the confusion and commonality of the barracks and of war has been rendered by the camera into a public moment for ever.

Other photographs are banal in a very different way. They represent moments or scenes out of daily life as if in effect there were no war at all. One photograph for instance shows a group of African women and children at work preparing grains. A completely trivial scene and the only thing that is not trivial about it is the very fact that the photograph exists and that it was taken most probably by one of the Portuguese soldiers acting as a tourist or a voyeur and recording on film what he took to be exotic reality. One could expect that a large number of photographs of Africans might have been taken with a pseudo-ethnographic curiosity, motivated by prurient motives or at least to show back home what the "natives" were like. The number of such photographs is scarce in the published books but some are also included, enough to let one take them as examples of their genre. And yet other photographs are banal because they simply show their subjects as if, instead of being at war, the Portuguese were instead on holiday. These range from the beautiful postcard-like photograph of Africans bringing a boat to shore under a beautiful sky, to shots of Portuguese men, in civilian clothes, perhaps officers on leave, taking drinks on a terrace.

Two of the most banal of all the photographs considered partake of this semblance of normalcy. One of them shows a young elegant man on the canvas of a ship, slightly leaning overboard. He is the central and only figure in the snapshot and nothing besides the uniform, could even serve as an indication of war. It is amazing how the photographer was able to find a moment when that part of the ship was empty, when the camera could focus exclusively on the figure of a particular individual and thus elide all the masses of soldiers being taken on the same ship which also already took on its hold the coffins which invariably would be destined for some of those dapper young men. The other photograph shows a group of soldiers training with the aid of a large structure to jump from airplanes. The image in itself is banal and its sole interest might reside in the fact that one of the men has been caught half way though his jump and thus frozen for posterity as if suspended in mid-air. Like the other photographs just mentioned there is also nothing at all in this photograph which would indicate to the viewer exactly what is at stake in such training, how it could very easily be turned into a matter of life and death. By itself it is actually an affirmation of life and vitality, of manly athletic prowess and the figure of the smiling running black man at the bottom of the structure is the one point of the photograph that, perhaps inadvertently, competes with the jumping man for the viewer's attention.

At one point in the scene in which Helena shows Evita the secret photographs that come out of the coffer kept in the room set up as a pseudo-anthropological museum, she calls attention to Evita's husband: “'Vê aqui o seu noivo?' Ela queria que Evita visse. Era claro como a manhã que despontava que Helena de Tróia me havia trazido até àquela divisão da casa para que eu visse sobretudo o noivo. Agora o noivo estava no primeiro plano do fotógrafo" (133). One striking group of photographs can also be singled out from the hundreds of published photographs of the war: portraits of soldiers as warriors. The fact that in so many of the photographs only one soldier is depicted is in itself already singular if one takes into account the very nature of war as a process of massification that starts by deindividualizing people even before it becomes dehumanizing as well. But one can think of a 
variety of reasons for this though, from the desire to give a face to the war effort and thus undermine its results to the simple wish to keep a memory of oneself or of one's friend apart from the group. Army efficiency might well depend on the creating of a group bonding between previous strangers but the focus on one or another specific individual rather than going against that need might indeed form part of it already. The photographs that I have in mind, however, go clearly beyond those functional motives and, indeed, if not professionally taken, they seem so. In any case, they constitute portraits and are far removed from the snapshots that constitute the majority of personal photographs of the war. They also share a common quality and that is that they are invariably reproduced as full-page pictures, which draws even more attention to them.

In one of these photographs one sees a young soldier on an inflatable boat, fully alert, machine gun in his hands. His figure completely dominates the image even though behind him one can discern the figures of three other soldiers in yet another inflatable raft. At first glance one might even miss these other figures in the background. Once detected, their presence, however, blurred by the lens's aperture and reduced to a smaller scale due to perspective, actually serves to emphasize the importance of the figure being portrayed. The photograph is carefully framed. At the very center is the spot where the young man's heart should be. His feet are no longer within the picture but this in no way reduces the stature of the soldier as he is sitting on the edge of the rubber boat. Finger on the trigger he looks at the shore of what seems to be a narrow waterway amid dense vegetation. The machine gun sits on his lap and extends almost the whole width of the photograph, creating a quasi-diagonal line which is parallel to the soldier's shoulders and to his face, and which manages to impart just enough dynamism to the image, creating the necessary illusion of movement. The soldier seems to be carrying his duty with tense attention and the fact that he does not look into the camera, which probably was held by someone ahead of him in the same boat, adds to the intended effect of realism so that the photograph, although far from being a snapshot, tries to dissimulate its orchestrated nature in an attempt to pass itself off for a true and unmediated representation of a moment in the war. It is a picture one could display with pride or send home to loved ones.

There are also portraits of Africans that achieve a similar intensity. One is a smaller photograph of Amílcar Cabral, also in a boat. Although not seen alone - the boat has eight other occupants including two women - it is clearly a portrait of the rebel leader. Cabral is shown standing, his hands holding the buckle of his belt and his face looking directly at the camera with firmness. In a sense, one could think of these two photographs as complementary, one as much an icon of the heroic determination of the African people to achieve independence (no guns are visible) as the other is an icon of Portuguese obstination to keep control over the colonized territories. Both are equally eloquent in representing models of manly conduct and if anything one could comment that whereas the photograph of Cabral seems to irradiate self-assurance and openness, the photograph of the Portuguese soldier carries with it a sense of unknown and imminent danger. The narrowness of the waterway in this latter contrasts starkly with the wideness of the water of the former. The inclusion of such a photograph of Amílcar Cabral in Os Anos da Guerra is not a surprise given the intention behind the book to try to represent both sides and to give voice to both the Portuguese as well as the Africans. In a sense this is achieved as both photographs are consummate portraits of warriors even if Amílcar Cabral is not shown as armed.

Not all portraits of Africans come across as clearly. One for instance, although also occupying a full-page and depicting two men in a sort of uniform is far less clear as one of the men carries a gun but on his shoulder as if it were a simple shovel and the other holds a small child in his arms. The effect of such a portrait is necessarily more complex not only because it has two main figures but because here the bellic attributes have been toned down 
as much as possible. One can think of this as a representation of the human face of the independence fighters in full contrast with the official propaganda of the Portuguese state, but in any case the message denoted by the photograph is polyvalent. It too could be contrasted with another portrait of a Portuguese soldier carrying both a machine gun and a child on his shoulders. The machine gun points down and thus even though it is in the foreground and occupies the whole diagonal axis of the image, its threatening charge has been de-emphasized. The center of attention becomes the child who looks directly at the camera and who seems either fearful or questioning. Like the photograph just mentioned before this one too does not have a simple and clear meaning, but the contrast between the soldier and the child creates a harrowing tension that is completely absent of the previous photograph with the two men and a child. Both call attention that war does never just involve soldiers and that often children are its immediate victims. Both deflate somewhat the heroic representation of the soldier so evident in the photograph of the Portuguese soldier on a boat or at least transfer it into a realm of responsibility beyond the individual. But, even though the viewer cannot know the circumstances of either photograph, the smile of the African soldier holding the child stands in direct contrast with the expression on the face of the child being carried by the Portuguese soldier.

Even if a large number of the photographs of individual soldiers carry, however unwittingly, a touch of romanticizing the image of the soldier, there is one specific portrait of a Portuguese soldier which really stands out and it does not have really any counterpart in any portrait of African fighters. In the available photographs there are two portraits of African fighters, one a man, the other a woman, which have some approximation as they both concentrate on an isolated figure that appears as paradigmatic of the soldier. The portrait of the woman is less clearly so, as she does not stand in front of the camera and without knowing the circumstances in which the photograph was taken one cannot be certain whether it was posed or not or even whether the published image was not manipulated by enlarging and cutting. The portrait of the African fighter, conversely, is clearly posed and one would be tempted to think that both it and the image of the Portuguese soldier I want to discuss were taken by the same photographer, however unlikely that might be. In any case, even that image is not a match for the one of the Portuguese soldier and its romanticizing effect, though still present and intended, is tenuous in comparison.

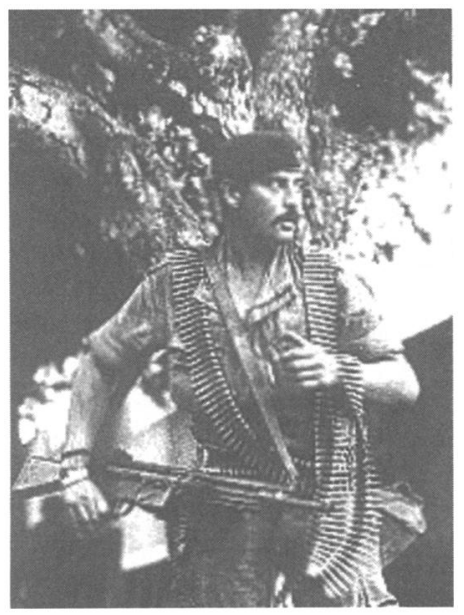


The photograph of the Portuguese soldier is a careful mise-en-scéne which both reveals its constructed nature as well as plays with the notion of verisimilitude and that makes it all the more fascinating. The background is completely out of focus even though one still recognizes a large tree behind the soldier and as if constituting an extension of his body. The soldier occupies the center of the image and dominates it even though his legs do not show below the knees. In uniform and with beret the soldier holds a machine gun with his right hand and is fully draped with ammunition belts which almost form a Moebius strip as they weave from the machine gun and across his shoulders through his left arm. He has been clearly instructed to look sideways and his whole body, slightly at an angle to the lens, appears to be in suspended motion even though he is static. It is obvious that he would never hold the machine gun in such a position, perpendicular to his hips but seemingly floating in the air and it is doubtful that he would ever be able to sustain the weight of the gun for long as it seems to be held solely by the finger on the trigger. The photograph could have been taken anywhere and the soldier depicted in this pose resembles more some Hollywood ideal of the romantic, mustache and all, virile hero, than anything else. And yet, not just in spite of, but precisely because of the photograph's hyperrealism, this image can also be seen as embodying a certain form of desire, capturing in this representation of manhood a whole national fantasy of power. The photograph's exaggerated pose and contrived overdressing all those bullets and that tree in the background - do have nonetheless a sort of counterimage and that is the photograph of a chimpanzee dressed up in camouflage and having a seven of spades for a badge.
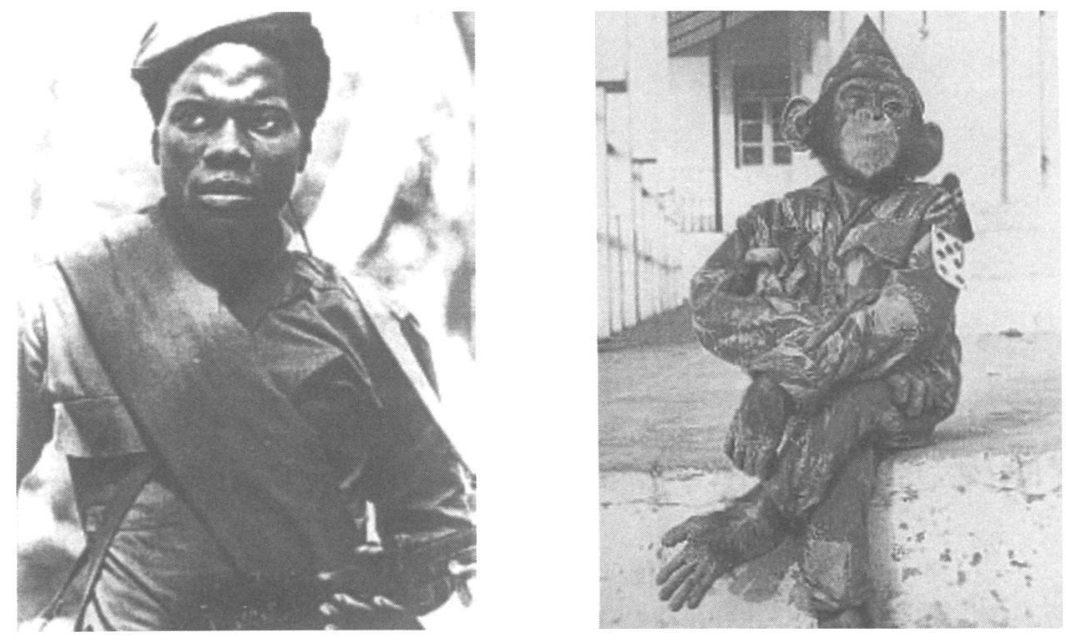

And what about death? Is not the overwhelming presence of death, even when not visible, and only hinted at, what distinguishes war photographs from other images? In a certain way, no. Or at least not categorically, for in theory at least all photographs do partake of death. But in another sense, of course death is the decisive factor. It is our knowledge that the crowd of young men boarding the ship may be going to meet their death which makes that photograph special even if that is not an intrinsic quality of the photograph itself. Nonetheless an important question still to be addressed concerns those photographs where death is not only connoted but explicitly denoted, where dead bodies are the object of representation. Curiously, from all of the published photographs there are only very few definitely showing a dead Portuguese soldier. There are some photographs showing coffins 
covered by the Portuguese flag and some showing grieving women and children but only one showing a laid soldier who might be dead but also just wounded. In another one sees two soldiers killed by mines and in one a Portuguese soldier is shown holding the head of a comrade lying on the ground and presumably dead. One knows that at least eight thousand soldiers were killed, one knows that the grief of the women and children is directed at the death of a loved one and one knows, or thinks to know, that those coffins must contain dead Portuguese soldiers. But their dead bodies are almost never visible as if this too were still a taboo too strong to break or even acknowledge.

Moeller provides a clue for this when she explains the direct link between explicit images of American casualties and negative public reaction strong enough to cause a change in policy: "Over time, a greater explicitness in the photography of combat prompted a greater sensitivity to American casualties, a greater reluctance to engage in certain kinds of exceptionally bloody warfare.... Visual portrayals of death and destruction began to outweigh the rhetorical arguments in favor of the wars" (6). But, at the same time, as she notes, photographic representation of enemy casualties, especially if other than caucasian, were admissible: "Indeed, it could be argued that the American penchant for bloodthirsty images is sated by the extraordinarily explicit photographs of the dead enemy that have appeared in print..." (7). Whereas such a split, however ideologically censurable, might still be easily pinned on psychological reactions to an ongoing conflict, the almost complete lack of photographs of dead soldiers and the inclusion of a number of sometimes very explicit photographs of dead Africans attests perhaps to a stronger reluctance to contemplate one's own death. Perhaps this absence can be explained by censorship, or by the inaccessibility to military archives, or even to the reluctance of families to keep, let alone publish, images of their dead ones. The photographs of dead Africans are shocking but in another sense so is the near absence of photographs of Portuguese casualties, as if, more than a decade after the end of the war and within a pacifist parameter, that truth were still too harsh to be confronted in the images to be published.

Can death ever be banal? One would like to think not but the realities of war and the elevated number of casualties all point to it. The death of someone whom one loves will never be banal but the deaths of others might. At least one can say that there are banal photographs of death and, somewhat stronger, that there are photographs which render visible how banal death can become under war circumstances. In some photographs one sees piles of dead bodies in front of buildings with some Portuguese, their noses and mouths covered, looking at them. It is obvious that the dead were carried and deposited there but the photograph cannot give any indication as to when and why they were killed and seems more a form of attesting to some kind of routine operation. Photographs of dead bodies lying on the grass by themselves appear to have no further interest than documenting that death. In one picture one sees several dead bodies, including that of a child, strewn on the grounds of some complex and while it is obvious that they were killed there, the photograph only raises questions and provides no answers. In one photograph in special, the extent to which death can come to be seen as banal is perhaps clearest. In it one sees a group of four men, one a Portuguese soldier, judging by his hat, the others possibly African men, walking towards some buildings, a village perhaps, along a dirt road, with their backs to the camera. In the foreground, on the right hand corner, lie the bodies of two Africans and as soon as the viewer's eye has stopped concentrating on them one realizes that all along the road, to the side but also in its middle, lie more dead bodies. And yet the four men walking do not seem in a hurry, no guns are visible, there is no sign whatsoever in their postures that this is anything out of the ordinary. One could well imagine a title for that photograph as if it were a genre painting, something like "Sunday walk in the countryside with dead bodies." 
In one photograph one sees a group of Portuguese soldiers hoisting dead bodies into a pile in a truck. Again, what is striking is not so much the gruesome nature of the task but the fact that the photograph depicts it as a task. Someone has to throw those dead bodies into the truck, and in the photograph it looks no different than if the soldiers were handling sacks of flour or cement or any other type of heavy load. And there is one other photograph in which a Portuguese soldier is seen pulling a dead African man by one of his legs in which what is strange is not so much the action being depicted but the way in which the photograph, perhaps because of its poor quality, renders the body of the dead man as if it were part of the landscape, as if it were a fallen tree trunk, which the Portuguese soldier were removing so as to clear a pathway. In the previously mentioned photographs depicting dead bodies, the connection between the dead and the Portuguese soldiers is tenuous and impersonal. One assumes that the dead people were killed by Portuguese soldiers or at least other Portuguese forces, but their death seems already at a temporal remove from when the photograph was shot. The piles of bodies in front of the buildings have been there for a while and had to be brought there first, the bodies of the women and child in the courtyard are by themselves, the individual dead bodies on the grass are also seen by themselves, and it seems highly improbable that the four men walking were directly involved in the killing of the people who lay on the side of the road. Even the soldiers loading the truck with bodies might have been sent there to clean up after some operation. But the photograph of the soldier pulling the dead man's leg is different and more direct with its one-on-one representation so that the viewer gets the sensation that it was that particular soldier who killed that particular man. Obviously that too might simply be an illusion, but this meaning is not just denoted, it is actually connoted by the image itself. For even if one does not see anything more than one man pulling a corpse by a leg, their seeming isolation from everything and everyone else forces that interpretation in the viewer's mind who reads the photograph as if it depicted the end result of a man-to-man combat in nature, the victor taking away its prey.

Two other photographs that create a similar illusion should be mentioned. In one of them there lies on the foreground the dead body of a black man in civilian clothing. Standing next to him and occupying the whole of the right side is the figure of a Portuguese soldier holding a machine gun still pointed at the dead body. On the background, to the left, one sees three soldiers walking away from the scene in the foreground and already at some distance. Although in this image there is no pretension that the soldier and the dead man are isolated - and I say pretension because the photograph of the soldier pulling the corpse by the leg was obviously taken by someone other than the soldier who had to be there - there is still an attempt at representing a direct link between the corpse on the ground and the soldier standing by it. The relation is unclear as it is improbable that the soldier would be guarding the corpse as much as it is improbable that he just happened to go by the corpse and stopped for a bit while the other three soldiers kept walking. The gun is still pointed at the corpse but the aim would have been wrong. Besides, if the soldier had just killed the man at his feet would the other three soldiers keep on walking without pausing to see what the shots were about? Even in war death does not become that banal. And there is one other striking element in this image and that is the fact that either owing to the angle itself or, more probably, to the cropping, the head of the soldier with the gun has been left off, creating an eerie effect of a headless soldier pointing a "needless" gun at an already dead body. The original photograph (assuming it showed the soldier's face) might well have been documentary of war action - even though there is no gun visible by the dead man's body but the published photograph is like a fantasmatic allegory of senseless colonial murder, a headless, senseless, body imposing its will over the (dead) body of the African man while the three other soldiers walk on the grass impervious to the drama enacted or re-enacted in the foreground. 
The other photograph that creates the illusion of a one-on-one combat is even more complex. It occupies a full page and most of its area is taken by the image of the corpse of a young black man. His head occupies the center of the photograph and the viewer can clearly see his face since the torso is being lifted at an angle from the ground. Behind the corpse one sees the figure of a Portuguese soldier, whose face is only partially visible, holding a machine gun. A first look into this photograph most probably will cause the viewer to see a direct connection between the two men, the dead African and the Portuguese soldier who seems to be holding the head of the man he just killed so as to display it to the camera as if it were a hunting trophy. The fact that the soldier's face is only partially visible seems odd, especially since the face of the black man takes precisely the center of the image and, being, on the foreground, appears much larger. But then showing only half his face, making it difficult for anyone to identify it might also be a way to both claim the deed and evading responsibility. As soon as one is able to abstract from the violence of the image, one is confronted with several questions for it is impossible, given their respective positions, that the Portuguese soldier might be the one whose hands hold the lifeless torso. Indeed, one can then recognize on the right side the figure of another Portuguese soldier, his face barely visible in the upper right corner. It is to this soldier that the pair of hands holding the dead man belong and not, as was assumed, to the soldier seen behind the dead man. It is this soldier then, who almost does not figure at all in the photograph, who is actually raising the corpse and displaying it to the camera very much as if it were a hunting trophy. There is no doubt that he has, or claims, a direct linkage to the corpse and yet he is almost invisible and unidentifiable himself.

Many of the photographs of the colonial war are shocking, either by themselves or by the feelings they evoke or the meanings they connote. Even the seemingly most banal photographs can be seen under this light and the banalization of death and violence is in itself another shocking result. However, it must be said that even though the portraits of the fighters often tend to romanticize them, death itself is never, at least in the photographs published so far, romanticized. Even the photographs of the coffins covered by the Portuguese flag are sober and avoid any form of spectacularity. The photographs that gather some effect of spectacle, macabre as it may be, are the ones displaying the heads of killed Africans. Lídia Jorge's narrative also alludes to some like it: "Helena mostrou-me com precaução o pacote que dizia spoilt como os outros e Víbora Venenosa III. Mais rostos, mais cabeças de soldados escondidos entre sarças, mais incêndios, e logo a imagem dum homem caído de bruços, depois dois telhados, e sobre um dos telhados de palha, um soldado com a cabeça dum negro espetada num pau" (133). Even in the last photograph I just mentioned, the way in which the almost invisible Portuguese soldier lifts the head of the dead man from the ground already draws the viewer's attention to it. This contrasts, quite uncannily, with the other photograph in which the Portuguese soldier aiming at a corpse on the ground is himself displayed as headless. But the most shocking pictures are the ones in which the cut off heads of black men are displayed. In one photograph, seemingly referring to the initial stages of the conflict, after the uprisings in Ucua, one can see a group of six Portuguese soldiers posing with the cutoff head of a black man impaled on a stick. Three of the soldiers are sitting down; behind them, three others stand. The one soldier in the middle holds a large knife in his right hand and with the left hand he holds the back of the impaled head, looking up at it with a clear expression of satisfaction. The soldier to his left also looks smilingly at the head and the brutality of the scene is inescapable. This is the most blatant of the published photographs but what it depicts, judging by the other photographs, was not a unique isolated instance, and indeed one can only wonder what other photographs - if not lost by accident or destroyed on purpose - are still locked up in private or institutional coffers. 
What distinguishes that photograph from others depicting heads of killed Africans, is the inclusion of the soldiers in the photograph as well as a clear road sign that identifies the scene with some precision. All other photographs lack any such details. In a photograph one can see the head of a black man impaled on a stick and it is obvious that it has been lying on the ground but the photograph leaves everything else out of range. Another of the published photographs shows three cut-off heads of African men lying in a row on the ground. They occupy the entire photograph and are at displayed at a slight angle that lets one see clearly that they have been placed on the ground. The head on the left wears a cloth band and the one in the middle is blindfolded which hints at some kind of execution. The brutality and sadism that such a photograph portrays are inescapable. And the viewer, certainly at a temporal remove, is left with a whole host of unanswered questions. Who closed the eyes of the killed men and why? Does such a gesture still connote a remnant of human decency or does it on the contrary betray the fear that the open eyes in such heads might be too haunting? The useless blindfold on the center head becomes the focal point of the entire image. The killed man might have been prevented from actually seeing his killers at the precise moment of his death and damn them with his eyes, but in a sense he might as well represent a whole nation which was blindfolded by its government and which, a quarter of a century later, and also in a sense, in its inability or refusal to confront such a haunting part of its past, has still not managed to remove its figurative blinds.

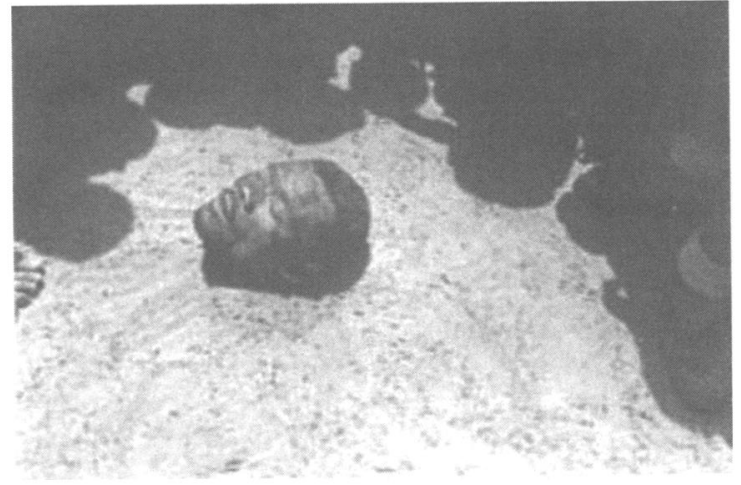

If these photographs avoid romanticizing death on the one hand, they, on the other, fetishize it. Silent yet eloquent witnesses to the monstrous brutality of the colonial war, the cut off heads of the killed black men function as fetishized objects of the soldiers's desire to control the African people, to dehumanize it, and to display their assumed superiority. One other photograph, of a cut-off head lying on the ground surrounded by a group of onlookers makes this explicit. Once again the eyes have been shut, but this time the face is looking up. The head is surrounded by a hemi-circle but one does not see the onlookers, one only sees their shadows projected on the ground and, on the left side, some toes of a naked black foot. The head is literally and figuratively the center of the attention and of the photograph, its drawing power undiminished in death, indeed, brought about by death and the subsequent mutilation. The onlookers are fascinated by the head and group around it and what makes this photograph gain in iconic effect is that all of these meanings are not only connoted they are denoted and yet none of the onlookers are there in the photograph beyond the few toes of a foot. The head holds power over the onlookers and, in the photograph, there is a direct link between them made by the fact that what one sees in effect is a disembodied head in the middle of the ground surrounded by the shadows of the heads of the people looking at it, 
which are themselves projected on the ground. Except for those toes the photograph is an assemblage of ghostly heads, the shadows of the heads of the onlookers even more immaterial than the head of the dead man which, as such, is really there whereas the others are merely projections. This photograph, like the overwhelming majority of the published photographs of the colonial war is an amateur snapshot, probably taken by one of the Portuguese soldiers to document life as it "really" was under the circumstances. Perhaps the shadows of the heads of the crowd around the cut-off head were not meant to be there. The central point of attention is the cut-off head and had the photographer had the opportunity, he would have composed his image so that nothing would disturb the representation of the object of his gaze. Those shadows and the few toes as well - themselves disembodied by the cropping of the photograph and the angle of the shot - probably are just accidental, not meant to be there at all. Probably. Or was this on purpose? Without identifying the photographer and examining the negative one will never know. But what is certain is that this photograph ends up synthesizing in itself what the photographs of the colonial war are and do. In a sense, it ends up by constituting a meta-discourse on war photographs, exposing them as constructions based on immaterial shadows of a very concrete materiality. "Vejo sombras" says Evita (136). The cut-off dead is alone and disembodied but metonymically linked to all of the living who look at it. And, in this image at least, the onlookers are the ones who are reduced to immaterial traces, while the head, though separated from the body, dead, and incapable of returning their gaze, stands alone as the only real human presence amidst a host of shadows.

\section{WORKS CITED}

Jorge, Lídia. A Costa dos Murmúrios. Lisboa: D. Quixote, 1988.

Devereaux, Leslie, and Roger Hillman, Eds. Fields of Vision: Essays in Film Studies, Visual Anthropology, and Photography. Berkeley: University of California Press, 1995.

Devereaux, Leslie. "An Introductory Essay." Fields of Vision, 1-20.

Hüppauf, Bernd. "Modernism and the Photographic Representation of War and Destruction." Fields of Vision, 94-126.

Moeller, Susan D. Shooting War: Photography and the American Experience of Combat. New York: Basic Books, .

Melo, João de, Ed. Os Anos da Guerra 1961-1975. Os Portugueses em África. Crónica, Ficção e História. 2 Vols. Lisboa: D. Quixote, 1988.

Monteiro, Renato, and Luís Farinha, Eds. Guerra Colonial: Fotobiografia. Lisboa: D. Quixote, 1990.

Rodrigues, Paulo Madeira, Ed. and José Cândido, graphic design. 4 Países libertados: Portugal, Guiné/Bissau, Angola, Moçambique. Lisboa: Bertrand, 1975. 